\title{
35 ANOS DE QUÍMICA NA SBQ
}

A Sociedade Brasileira de Química completou 35 anos de existência tendo 22 Secretarias Regionais, 13 Divisões Científicas e mais de 6.000 sócios, constituindo-se em uma das maiores sociedades científicas brasileiras e a maior sociedade científica da América do Sul.

No primeiro editorial publicado na Química Nova, escrito pelo Prof. Peixoto, encontramos a expressão paradigmática que a SBQ é um "ser coletivo com razões próprias e aparentemente alheio à vontade de cada um dos químicos que formam este ser coletivo". Sem dúvida que a frase é auspiciosa e atual.

Esse "ser coletivo" é o conjunto de associados e dos colegas que já não se encontram entre nós, mas que permanecem em nossos corações e mentes. Sim, eles conduziram os destinos da SBQ e nós temos a missão de continuar a sua história, tornando-a cada vez mais forte e representativa.

Esse editorial dos 35 anos da SBQ pretende homenagear os fundadores, colegas falecidos e os atuais membros que mantêm esse "ser coletivo" vivo e ativo.

Desde a sua criação, a SBQ vem atuando de forma expressiva no desenvolvimento da comunidade química do País apoiando novos talentos e lideranças, estabelecendo padrões acadêmicos, científicos e éticos para a área. Todas essas ações, consequentemente, trazem desenvolvimento para o país e para a melhoria da qualidade de vida dos cidadãos.

O desenvolvimento e o amadurecimento da SBQ dentro da comunidade química brasileira podem ainda serem evidenciados pelas suas 4 revistas científicas, que têm sido importantes para a divulgação da Química e a melhoria da sua imagem. Esses periódicos divulgam parte substancial da produção da pesquisa em Química, no contexto nacional e internacional. Recentemente, a SBQ ultrapassou as formas mais tradicionais de disseminação do conhecimento científico para novas tecnologias de comunicação como blogs, twitter, facebook e o portal QUID+, dirigido a jovens a partir de 10 anos, que tem como objetivo estimular o leitor de tênue idade para a Química, sua inserção no cotidiano e despertá-lo para as ciências químicas.

As nossas Reuniões Anuais congregam mais de 3000 participantes, com uma produção média de 1800 comunicações de pesquisa e com a participação expressiva de jovens.
A SBQ tem se internacionalizado com a aproximação com outras sociedades científicas. Hoje somos a entidade representante da Química brasileira junto à IUPAC.

Apesar do nosso ser coletivo ter avançado muito nestes 35 anos, temos desafios pela frente. Precisamos contribuir para diminuir as imensas desigualdades no Brasil, onde coexistem regiões mais desenvolvidas e outras de extrema miséria, onde a água é o bem mais precioso. Temos que colocar os seres humanos como o centro das preocupações para o desenvolvimento sustentável, pois esse país precisa de soluções urgentes e a SBQ pode contribuir em muito nas discussões dos grandes temas nacionais como fome, pobreza, doenças, desarmamento, discriminação racial, meio ambiente, biodiversidade e eficiência econômica com justiça social.

Tendo como paradigma que a compreensão humana sobre a natureza é baseada no conhecimento da Química, a nossa responsabilidade aumenta e bem sabemos que os objetivos econômicos, sociais e ambientais só podem ser alcançados com o progresso social.

A Química pode contribuir em muito para um desenvolvimento sustentável, melhorando os produtos consumíveis com novos materiais mais adequados às necessidades atuais, novos métodos de produção de fármacos e produtos químicos intermediários, substituição dos combustíveis fósseis não renováveis e utilização de novas fontes energéticas. Isso se chama uma Química ambientalmente consciente e centrada nos seres humanos.

Estas não são as únicas ações dentro do complexo e diversificado panorama da sustentabilidade, mas as palavras precisam ser transformadas em ações efetivas. Ainda há muito a avançar nesta direção, pois só temos um planeta e o futuro não pode esperar. Se desejarmos ter uma Química forte e desenvolvida no Brasil, é preciso ter uma Química ampla e forte em todos os estados.

Vitor F. Ferreira

Presidente da $S B Q$ 